\title{
Fast and Slow Nerve Growth Factor Binding Sites in Human Neuroblastoma and Rat Pheochromocytoma Cell Lines: Relationship of Sites to Each Other and to Neurite Formation ${ }^{1}$
}

\author{
KENNETH H. SONNENFELD ${ }^{2}$ AND DOUGLAS N. ISHII \\ Department of Pharmacology and the Cancer Research Center, College of Physicians and Surgeons of Columbia University, \\ New York, New York 10032
}

\begin{abstract}
We studied (a) the distribution and properties of fast and slow ${ }^{125}$-nerve growth factor ( ${ }^{125}$-NGF) binding sites in cultured human neuroblastoma (NB) cell lines that were categorized as responsive $\left(\mathrm{N}^{+}\right)$or unresponsive $\left(\mathrm{N}^{-}\right)$to $\mathrm{NGF}$ by neurite outgrowth, (b) whether fast or slow sites mediate actions of NGF, and (c) whether NGF-mediated conversion of fast to slow sites occurs in human NB and pheochromocytoma PC12 cells.

In human NB SH-SY5Y cells, the slow sites were trypsin resistant and binding was of high affinity. Loss of binding to the slow sites had a half-time of 25 to $30 \mathrm{~min}$ at $37^{\circ} \mathrm{C}$ and was very slow at $4^{\circ} \mathrm{C}$. In contrast, the fast sites were trypsin sensitive and binding was of lower affinity; its dissociation half-time was less than $1 \mathrm{~min}$ at $4^{\circ} \mathrm{C}$ and $37^{\circ} \mathrm{C}$. The association rate constants of both sites were about 0.8 to $1.2 \times 10^{7}$ $\mathrm{M}^{-1} \sec ^{-1}$.

Some human NB cells had both fast and slow sites. The $\mathrm{N}^{+}$human NB lines SH-SY5Y and LA-N-5 had only slow sites. Despite the virtual elimination of fast sites by trypsin in NB MC-IXC cells, remaining slow sites could still efficiently bind ${ }^{125}$ I-NGF. These observations showed that fast sites are not required for slow site binding, neurite outgrowth, or other demonstrated actions of NGF in some NB cells. In PC12 cells, 125I-NGF initially bound to fast sites was not directly transferred to slow sites as required for NGF-mediated conversion. The association rate constants of fast and slow sites in PC12 cells were both about $2 \times 10^{7} \mathrm{~m}^{-1} \mathrm{sec}^{-1}$. The association kinetics were consistent with simple bimolecular reactions in both NB and PC12 cells. The combined evidence in NB and PC12 cells did not support the hypothesis of NGF-mediated conversion of fast to slow sites.
\end{abstract}

Received July 1, 1983; Revised November 2, 1984;

Accepted November 27, 1984

\footnotetext{
'We thank John F. Mill for assistance in word processing and Edward Dross for instruction in computerized plotting. This study was supported in part by Grant R01 NS 14218 from the National Institute of Neurological Communicative Diseases and Stroke. K. H. S. was supported partly by the Mamie and Dr. S. C. Wang Predoctoral Fellowship, and by United States Public Health Service Training Grant GM 07182 from the Division of General Medical Sciences. D. N. I. was the recipient of United States Public Health Service Research Career Development Award 1K04 NS 00375.

${ }^{2}$ Present address: Neurology Department, Mt. Sinai School of Medicine, New York, NY 10029.

${ }^{3}$ To whom reprint requests should be addressed.
}

The nerve growth factor (NGF) is an important prototype neurotrophic factor which can enhance neurite outgrowth, growth, and development in sensory, sympathetic, and fetal adrenal chromaffin cells (Mobley et al., 1977a, b, C; Bradshaw, 1978; Aloe and LeviMontalcini, 1979). Two types of ${ }^{125}$-NGF binding sites are present, which have similar association but different dissociation rates, in chick sensory ganglion cells (Sutter et al., 1979). Two types of sites, which have been termed fast and slow, based on their rates of loss of binding, are also present in pheochromocytoma PC12 cells (Schechter and Bothwell, 1981). The sites in PC12 cells have additionally been referred to as low and high affinity, respectively, by others (Landreth and Shooter, 1980). The slow sites are resistant, whereas the fast sites are sensitive to trypsin digestion. Fast and slow sites extracted from melanoma cells and reconstituted into liposomes retain differences in dissociation rates and sensitivity to trypsin (Buxser et al., 1983). Whether it is the fast sites, the slow sites, or both that are receptors for the actions of NGF is unsettled. The two sites may be related in some way. For example, the possibility has been raised that binding of NGF may convert fast sites to slow ones, partly because ${ }^{125}$.-NGF bound to fast sites is reported to be transferred to slow sites in PC12 cells (Landreth and Shooter, 1980; Shooter et al., 1981).

We have used the cultured human neuroblastoma (NB) cell as a model in which to investigate the mechanism of NGF-directed neurite extension, and the relationship between phenotypic expressions of maturation and the cell growth rate (Sonnenfeld and Ishii, 1982; Spinelli et al., 1982). In clonal human NB SH-SY5Y cells (Biedler et al., 1978), NGF increases neurite outgrowth (Perez-Polo et al., 1979; Sonnenfeld and Ishii, 1982), protein content (Sonnenfeld and Ishii, 1982; Spinelli et al., 1982), and veratridine-dependent $\mathrm{Na}^{+}$uptake (Perez-Polo et al., 1979). The neurites in SH-SY5Y cells have an ultrastructure similar to that of developing sympathetic ganglion cells and end in structures typical of neuronal growth cones (Burmeister and Lyser, 1982). NB cell lines responsive $\left(\mathrm{N}^{+}\right)$and unresponsive $\left(\mathrm{N}^{-}\right)$to the stimulatory effects of NGF on neurite outgrowth have been identified (Sonnenfeld and Ishii, 1982; Recio-Pinto and Ishii, 1984). The aims of this study were: (a) to define further the properties of ${ }^{125}$ I-NGF binding sites in human NB cell ines, $(b)$ to determine whether the fast or slow sites are the receptors regulating neurite outgrowth, and (c) to determine whether NGF-mediated conversion of fast to slow sites occurs in human NB and PC12 cells.

We report that fast sites are required neither for neurite outgrowth nor for the binding of NGF to slow sites.

\section{Materials and Methods}

Materials. NGF (the $\beta$-subunit) was isolated from saliva of male SwissWebster mice (Varon et al., 1968; Burton et al., 1978); purity was confirmed by the presence of a single band on isoelectric focusing ( $\mathrm{pH} 3.5$ to 10) in $7.5 \%$ polyacrylamide gels, and on electrophoresis in sodium dodecyl sulfate polyacrylamide gels. In a modified bioassay, $1 \mathrm{ng} / \mathrm{ml}$ of NGF was equivalent 
to 1 biological unit (Ishii and Shooter, 1975). Molarity calculations are based on dimer $M_{\mathrm{r}}=26,500$.

The following cell ines were studied. The passage number is indicated by "P." Human NB line IMR-32 (P47) (Tumilowicz et al., 1970) was obtained from the American Type Culture Collection ((CCL 127); Rockville, MD); uncloned CHP-100 (P100), and CHP-134 (P93) (Schlesinger et al., 1976) were kind gifts of Dr. H. R. Schlesinger; uncloned lines SK-N-SH (P26) and SK-N-MC (P55) (Biedler et al., 1973) and their cloned sublines SH-SY5Y (P6, P36), SHEP (P23), and MC-IXC (P38) (Biedler et al., 1978) were the generous gifts of Drs. June L. Bicdler and Barbara A. Spengler; and the rat pheochromocytoma clone PC12 (P36) (Greene and Tischler, 1976) was a kind gift of Dr.Lloyd A. Greene. LA-N-5 (P42) was kindly provided by Dr. Robert C. Seeger. The human NB cell lines are classified as responsive $\left(\mathrm{N}^{+}\right)$or unresponsive $\left(\mathrm{N}^{-}\right)$ with respect to NGF-stimulated neurite outgrowth (Sonnenfeld and Ishii, 1982; Recio-Pinto and Ishii, 1984)

Cell Culture. Cells were maintained in the logarithmic phase of growth in plastic tissue culture flasks in Roswell Park Memorial Institute Medium 1640 (RPMl 1640) supplemented with $15 \%$ fetal calf serum, 50 units $/ \mathrm{ml}$ of sodium penicillin-G, and $25 \mu \mathrm{g} / \mathrm{ml}$ of streptomycin sulfate at $37^{\circ} \mathrm{C}$ in humidified $5 \%$ $\mathrm{CO}_{2} / 95 \%$ air. Cells were passaged following treatment of cultures with $0.05 \%$ trypsin and $1 \mathrm{~mm}$ EDTA in Hanks' salts solution and dispersion by trituration. Trypsin was not required for passage of SK-N-MC, MC-IXC, or CHP-134 cells.

For experiments, cells that had been fed the previous day were harvested in Hanks' salts solution containing $1 \mathrm{~mm}$ EDTA, and clumps were dispersed by trituration. Separate aliquots of the cell suspension, except from lines which could be passaged without tyrpsin treatment, were incubated for 10 min at $37^{\circ} \mathrm{C}$ with $0.05 \%$ trypsin, and the viable cell count was determined in a hemocytometer, using trypan blue dye exclusion to estimate viability.

lodination of NGF. Purified $\beta$-NGF was iodinated with lactoperoxidase and carrier-free $\mathrm{Na}^{125}$ to 0.1 to $0.3 \mathrm{~mol}$ of ${ }^{125} \mathrm{l} / \mathrm{mol}$ of monomer NGF (Ishii, 1978: Sonnenfeld and Ishii, 1982). At least $96 \%$ of the ${ }^{125}$-NGF was precipitable in cold $10 \%$ trichloroacetic acid, and it was immunoprecipitable with rabbit antiNGF antiserum (Ishii and Shooter, 1975).

Incubation conditions. Generally, cells (2 to $4 \times 10^{6} / \mathrm{ml}$ ) were incubated in RPMl 1640 medium containing $5 \mathrm{mg} / \mathrm{ml}$ of bovine serum albumin, $25 \mathrm{mM}$ HEPES buffer, $\mathrm{pH} 7.4$, and ${ }^{125}$.NGF. All solutions were passed through a $0.22-\mu \mathrm{m}$ filter or were centrifuged at $9,000 \times g$ for $10 \mathrm{~min}$ before use. At 0.1 $n{ }^{125}$-NGF, binding was linear over the cell concentrations used and was not limited through depletion of labeled ligand within the intervals studied. Noncompetitive binding was determined in parallel incubations additionally containing $10 \mathrm{nM}$ NGF at the onset in the case of SH-SY5Y cells, or $400 \mathrm{nM}$ NGF in the case of MC-IX cells, for reasons to be discussed.

Binding assay. The centrifugation binding assay (Sonnenfeld and Ishii, 1982), with pertinent modifications, is briefly described. Binding sites with properties similar to those of fast and slow sites on PC12 cells (Schechter and Bothwell, 1981) are present on human NB cells. After incubation for 10 min on ice with $400 \mathrm{nM} \mathrm{NGF,} \mathrm{binding} \mathrm{to} \mathrm{fast} \mathrm{sites} \mathrm{is} \mathrm{quantitatively} \mathrm{lost} \mathrm{and}$ the remaining residual binding is to slow and noncompetitive sites. Binding to slow sites is defined as the difference between residual and noncompetitive binding. Binding to fast sites is defined as the difference between total and residual binding. It will be shown that the slow sites are high aftinity and fast sites are lower affinity. In cell lines in which fast sites are absent, residual binding was defined with $10 \mathrm{nM}$ NGF present at the onset of incubation, since all specific binding is displaced. But, in cell lines with fast sites, residual binding was defined with $400 \mathrm{nM}$ NGF in order to completely displace the specific binding additionally due to the lower affinity fast sites. Incubates were subjected to equilibrium sedimentation for $30 \mathrm{sec}$ in a Beckman model 152 Microfuge (Beckman Instruments, Inc., Palo Alto, CA), and the cell pellet fraction was assayed for radioactivity content. The cell-free supernatant fraction was also counted to determine the amount of nonbound radioactivity in some experiments. Due to the small number of binding sites in SH-SY5Y cells, to minimize background it is important to use needle-rlosed $400-\mu 1$ microcentrifuge tubes with tip volumes of about $1 \mu \mathrm{l}$ (W. Sarstedt, Inc., Princeton, $\mathrm{NJ}$ ). Cell lines in which binding to fast sites is absent could also be studied by sedimentation on sucrose gradients (Herrup and Shooter, 1973), a procedure in which cells are not continually exposed to labeled ligand during centrifugation. However, because of the rapid half-time of dissociation, cell lines with fast sites were studied only by the method of equilibrium sedimentation; otherwise, recovery of binding is incomplete due to dissociation during sedimentation through the sucrose gradient, as can be predicted (Williams and Lefkowitz, 1978).

Association rate constants. The $37^{\circ} \mathrm{C}$ rate constant of association was determined by the method of Moore (1962). Basically, the time course of binding was determined at four different concentrations of ${ }^{125}$.NGF, with and without 100 - or 1000-fold excess NGF. For the binding curves at each concentration, the initial velocity, $V_{0}$, of specific fast or slow site binding, determined from the initial slope of the time course curve, was plotted against each ${ }^{125}$ I-NGF concentration. Then, the following second-order rate equation was used to calculate the rate constant, $k_{+1}: V_{0}=k_{+1}$ (NGF)(R), where $(R)$ is the concentration of receptor sites determined from the Scatchard analysis of binding.

\section{Results}

Time and temperature-dependent distribution of ${ }^{125}$ /-NGF binding in MC-IXC and SH-SY5Y cells. MC-IXC cells have both fast and slow sites. Total binding at $37^{\circ} \mathrm{C}$ to $\mathrm{N}^{-}$MC-IXC cells (Fig. $1 A$ ) attained a maximum value within $10 \mathrm{~min}$, then rapidly declined to a plateau. The rapid decline shall be called attenuation rather than down regulation since the functional significance is not described here. Total binding at $4^{\circ} \mathrm{C}$ was less than at $37^{\circ} \mathrm{C}$, and attenuation was absent (Fig. 1C). Following subtraction of noncompetitive binding, the analysis of specific binding showed that the attenuation observed at $37^{\circ} \mathrm{C}$ was due to a decline in binding to fast sites (Fig. 1B). Binding to fast sites was complete within 5 to $7 \mathrm{~min}$ at $4^{\circ} \mathrm{C}$, and the attenuation of binding was not observed (Fig. 1D). Binding to slow sites was slower at $4^{\circ} \mathrm{C}$ than at $37^{\circ} \mathrm{C}$; at neither temperature was attenuation of slow sites observed in MC-IXC cells. Greater than $94 \%$ of the radioactivity released from MC-IXC cells remained precipitable in $10 \%$ trichloroacetic acid. Attenuation could not bc cxplained by degradation and a subsequent decrease in the ligand concentration, because $99 \%$ and $95 \%$ of the NGF remained acid precipitable following $2 \mathrm{hr}$ incubation with SH-SY5Y and MC-IXC cells, respectively.

Binding to $\mathrm{N}^{+} \mathrm{SH}-\mathrm{SY} 5 \mathrm{Y}$ cells is shown in Figure 2. In contrast to MC-IXC cells, fast sites were not observed in SH-SY5Y cells. At all times, total and residual binding had the same measured values at $37^{\circ} \mathrm{C}$ (Fig. 2, lett), showing the absence of fast sites. The results were the same whether measurements were made by the equilibrium sedimentation method or by the sucrose gradient method. The binding to slow sites increased to a transient maximum followed by attenuation. The possibility that a rapid conversion at $37^{\circ} \mathrm{C}$ might obscure detection of fast sites was considered. To that end, binding was also studied at $4^{\circ} \mathrm{C}$ to determine whether fast sites were observable under conditions in which the rate of binding and putative conversion to slow sites should be substantially reduced. The maximum binding at $4^{\circ} \mathrm{C}$ was reached only after 7 to $9 \mathrm{hr}$ (Fig. 2, right). After 10 min at $4^{\circ} \mathrm{C}$ less than $10 \%$ of the available specific sites were occupied, none of which were fast sites. Under the same conditions of time and temperature, fast sites were maximally bound in MC-IXC cells (Fig. 1D). Although $10 \mathrm{nM}$ NGF was used in this experiment to determine residual binding, the use of $400 \mathrm{nM}$ NGF in other experiments failed to reveal the presence of fast sites. Attenuation of slow site binding was not observed at $4^{\circ} \mathrm{C}$.

In $\mathrm{N}^{+}$LA-N-5 cells, the time course and distribution of binding were very similar to those in SH-SY5Y cells, and all specific binding was to slow sites (Sonnenfeld and Ishii, 1982). Attenuation of slow sites was observed in two $\mathrm{N}^{+}$lines (SH-SY5Y and LA-N-5), but not in three $\mathrm{N}^{-}$lines (MC-IXC, CHP-100, and CHP-134). The time course and magnitude of attenuation were variable.

Noncompetitive binding increased with time at a constant rate in MC-IXC (Fig. 1A) and SH-SY5Y (Fig. 2, left) cells. These sites are most likely on the cell surface since the binding was highly sensitive to trypsin treatment (data not shown).

Association rates of fast and slow sites in human NB and PC12 Cells. To compare further the properties of fast and slow sites, and to determine whether binding behaves as a bimolecular reaction, the association rates were measured. The rate constants of association, $k_{+1}$, were measured at $37^{\circ} \mathrm{C}$ by studying the initial velocity of binding. This method is attractive because attenuation (Figs. 1 and 2) and other potential secondary binding events can be neglected at very early times.

In Figure $3 A$, there was no evidence of a lag in binding to slow sites in SH-SY5Y cells, as might be expected from the model of 


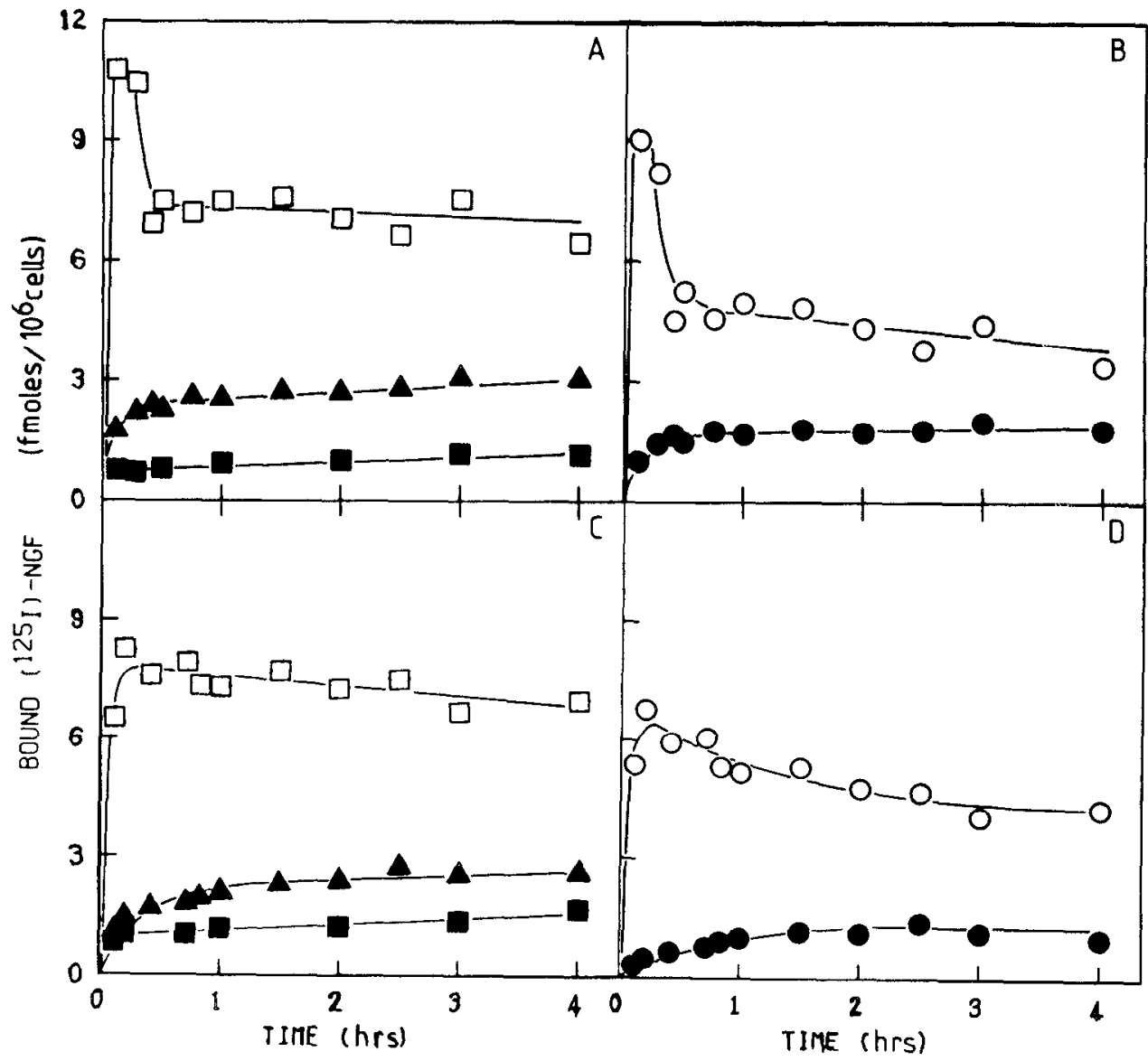

Fig. 1. Figure 1. Time course of ${ }^{125} \mathrm{I}-\mathrm{NGF}$ binding at $37^{\circ} \mathrm{C}$ and $4^{\circ} \mathrm{C}$ in MC-IXC cells. Cells were incubated with $0.1 \mathrm{nM}{ }^{125}$-NGF alone and with $400 \mathrm{nM} \mathrm{NGF}$ for $4 \mathrm{hr}$ at $37^{\circ} \mathrm{C}$ and $4^{\circ} \mathrm{C}$. Total $(\square)$, residual $(\Delta)$, and noncompetitive $(\square)$ binding at $37^{\circ} \mathrm{C}(A)$ and $4^{\circ} \mathrm{C}$ (C). Specific Fast $(O)$ and Slow (O) site binding at $37^{\circ} \mathrm{C}(B)$ and $4{ }^{\circ} \mathrm{C}(D)$ are indicated.

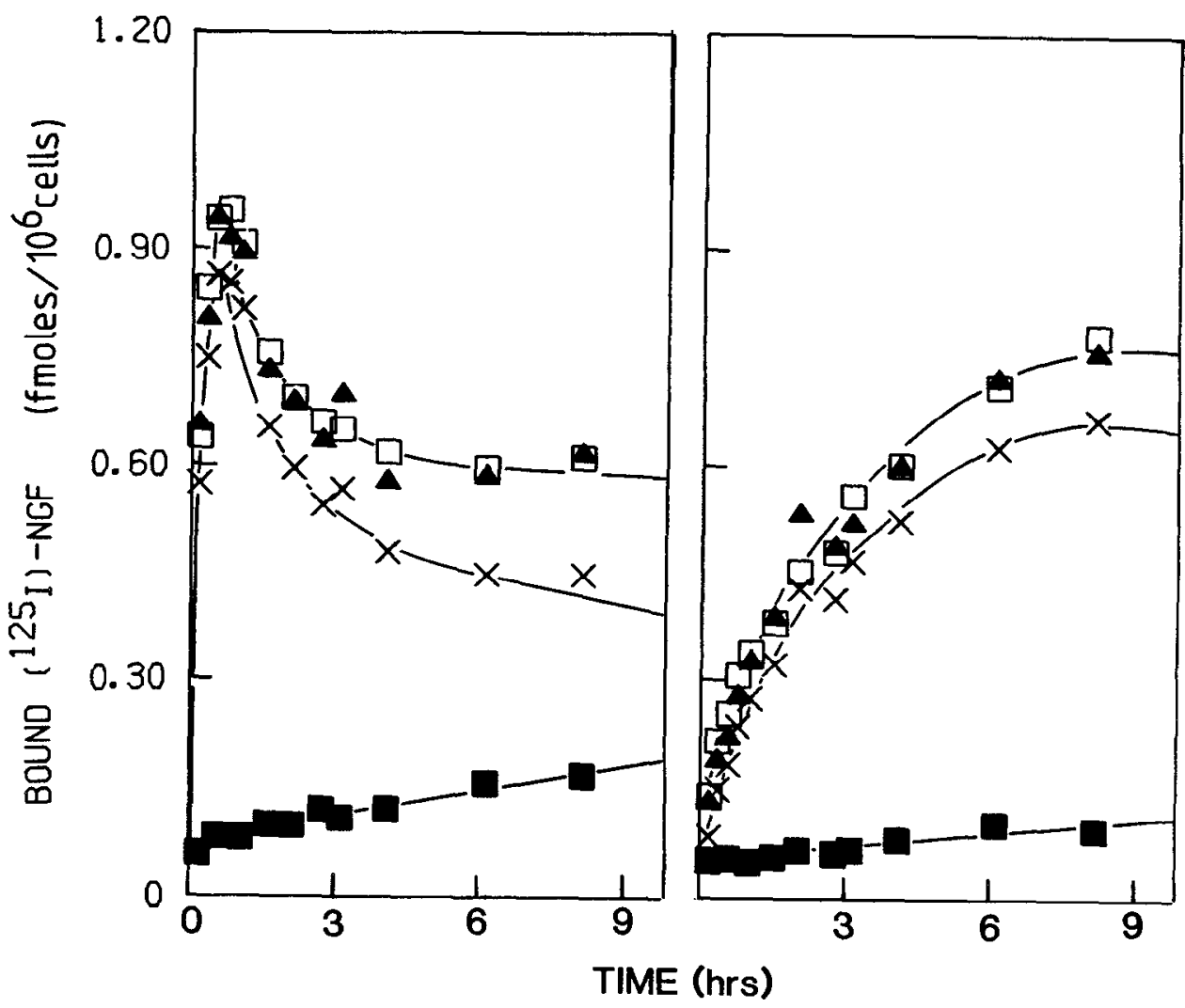

Figure 2. Time course of 1251 -NGF binding at $37^{\circ} \mathrm{C}$ and $4^{\circ} \mathrm{C}$ in SH-SY5Y cells. Cells were incubated with $0.1 \mathrm{nM}^{125}$-NGF alone and with $10 \mathrm{nM} N \mathrm{NGF}$ at $37^{\circ} \mathrm{C}$ (left) and $4^{\circ} \mathrm{C}$ (right). Total $(\square)$, residual $(\boldsymbol{\Lambda})$, noncompetitive (a), and specific slow site $(x)$ binding are indicated. 

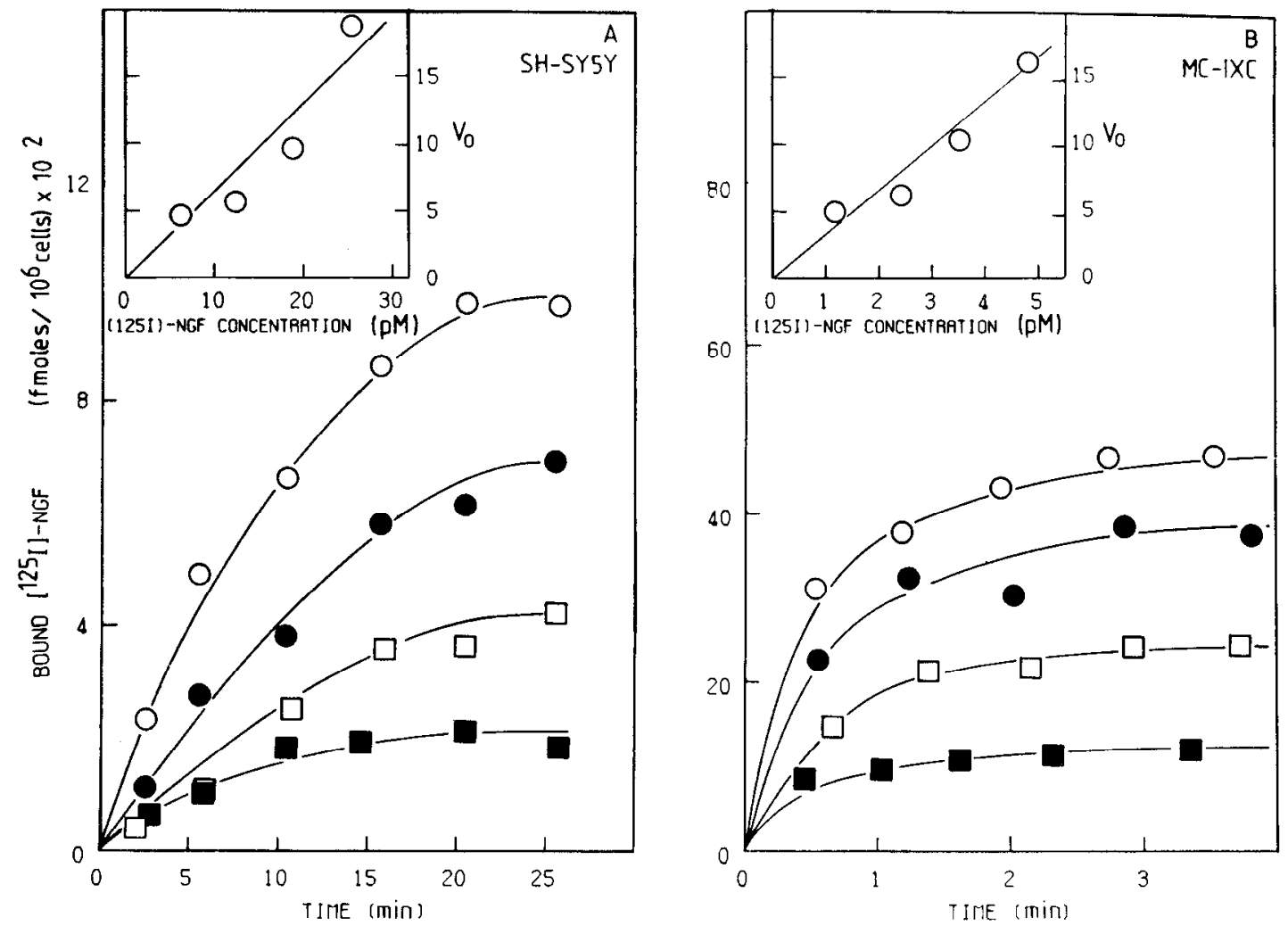

Figure 3. The $37^{\circ} \mathrm{C}$ association rate constants of slow sites in $\mathrm{SH}-\mathrm{SY} 5 \mathrm{Y}$ and fast sites in $\mathrm{MC}-\mathrm{IXC}$ cells. Cells were incubated at $37^{\circ} \mathrm{C}$ with four different concentrations of ${ }^{125}$ I-NGT as shown, in the absence and presence of $10 \mathrm{nM}$ NG厂 for SH-SY5Y and $400 \mathrm{nM}$ NGF for MC-IXC cells. A shows the time course of specific slow site binding with $6.2(\square), 12.3(\square), 18.8(\odot)$, and $25.4(O)$ pM ${ }^{125}$-NGF in SH-SY5Y cells. In the inset, the initial velocity, $V_{0}$, was determined from the initial slope of each time course curve and plotted against the appropriate concentration of ${ }^{125}$-NGF. $B$ shows the data for specific fast site binding to $\mathrm{MC}$-IXC cells with the indicated four concentrations of ${ }^{125}$-NGF and corresponding symbols. Binding to slow sites has been subtracted.

NGF-mediated conversion of fast to slow sites shown in formula 1. At each concentration of ${ }^{125} \mathrm{~F}-\mathrm{NGF}$, the binding curves appeared to pass through the origin. Assuming a second-order reaction, the rate equation described by Moore (1962) was applied. The plot of $V_{0}$, the initial velocity of binding, versus the ${ }^{125}$-NGF concentration is shown in the inset to Figure $3 A$. The data were plotted by the method of least squares (coefficient of correlation, $r=0.96$ ). The slope of the curve divided by $(R)$, assuming a value of 580 slow sites/cell (Fig. 9A), yielded a $k_{+1}=8.1 \times 10^{6} \mathrm{M}^{-1} \mathrm{sec}^{-1}$, which was the average of two experiments. This value is dependent on the assumption that the same number of receptors is initially present on the cells at $37^{\circ} \mathrm{C}$ as at $4^{\circ} \mathrm{C}$.

The data of Figure 2, right, for binding to slow sites at $4^{\circ} \mathrm{C}$ were also analyzed (Fig. 4). At the lower temperature, attenuation does not occur (Fig. 2), and the integrated rate equation for a bimolecular reaction (Shiu and Friesen, 1974; Stach and Wagner, 1982) could be applied. The $k_{+1}$ at $4^{\circ} \mathrm{C}=9.5 \times 10^{5} \mathrm{M}^{-1} \mathrm{sec}^{-1}$. The least squares plot of the data passed through the origin and was linear $(r=0.98)$. Thus, the association data for the slow sites obtained at $37^{\circ} \mathrm{C}$ and $4^{\circ} \mathrm{C}$, when taken together, were consistent with a simple bimolecular reaction

The association rate constant of fast sites in MC-IXC cells was measured at $37^{\circ} \mathrm{C}$ by the initial velocity procedure. Since there are many more fast than slow sites, and binding is more rapid, the time course of binding was studied between 0.5 and $3.5 \mathrm{~min}$ at four concentrations of ${ }^{125}$ I-NGF (Fig. 3B). Binding to slow sites has been substracted and only specific fast site binding is shown. The least squares plot of $V_{0}$ versus ligand concentration is shown in the inset to Figure $3 B(r=0.95)$. The $k_{+1}$ was about $12 \times 10^{6} \mathrm{M}^{-1} \mathrm{sec}^{-1}$, assuming $1.6 \times 10^{5}$ fast sites/cell (Fig. 9B). This showed that the $k_{+1}$ values of fast and slow sites in human NB cells are quite close.

The $k_{+1}$ values of fast and slow sites in PC12 cells were similarly measured by the initial velocity method. The value for slow sitcs was $2.2 \times 10^{7} \mathrm{M}^{-1} \mathrm{sec}^{-1}$ (Fig. 5), and that for fast sites was $2.3 \times 10^{7}$ $\mathrm{M}^{-1} \mathrm{Sec}^{-1}$ (Fig. 6). Thus, the association rate constants of fast and slow sites in PC12 cells were indistinguishable from one another. From these $k_{+1}$ values, and the dissociation rates (Schechter and Bothwell, 1981), it is evident that the fast sites are low and the slow sites are high affinity. In other studies, we estimated that there were 20,000 fast and 3,600 slow sites/cell (not shown); similar values can be calculated from the data of Schechter and Bothwell (1981). If only one NGF dimer binds to a single receptor molecule, the plot of $V_{u}$ versus NGF concentration should be linear, a condition which was satisfied for both fast $(r=0.99)$ and slow $(r=0.94)$ sites, and binding was consistent in both cases with a simple bimolecular process. Ihese findings serve to limit potential models of NGF binding, as will be discussed.

Rate of loss of bound radioactivity at $37^{\circ} \mathrm{C}$ and $4^{\circ} \mathrm{C}$ in $\mathrm{MC}-\mathrm{IXC}$ and $\mathrm{SH}-\mathrm{SY} 5 \mathrm{Y}$ cells. The temperature-dependent kinetics of loss of bound radioactivity from fast and slow sites in human NB cells are similar to those observed following incubation with ${ }^{125}$-NGF in other cell systems (Sutter et al., 1979; Olender and Stach,1980; Schechter and Bothwell, 1981). The studies were conducted after attenuation was complete to avoid its contribution to loss rates.

In MC-IXC, the rate of loss of binding was studied by simple addition of excess NGF (chase) as shown in Figure 7, left; chase was added at a time when attenuation was complete (Fig. 1). At $37^{\circ} \mathrm{C}$, the loss rate was biphasic. The half-time for loss from the fast sites, shown by the initial rapid phase, was difficult to measure with precision but was estimated as less than $1 \mathrm{~min}$; the half-time of loss from the slow sites, shown by the second, slower phase, was about $25 \mathrm{~min}$. At $4^{\circ} \mathrm{C}$, loss from the fast site was rapid and complete within 2 min, but less than $10 \%$ of the bound radioactivity was lost from the slow sites even after $50 \mathrm{~min}$. In the absence of added chase, a 


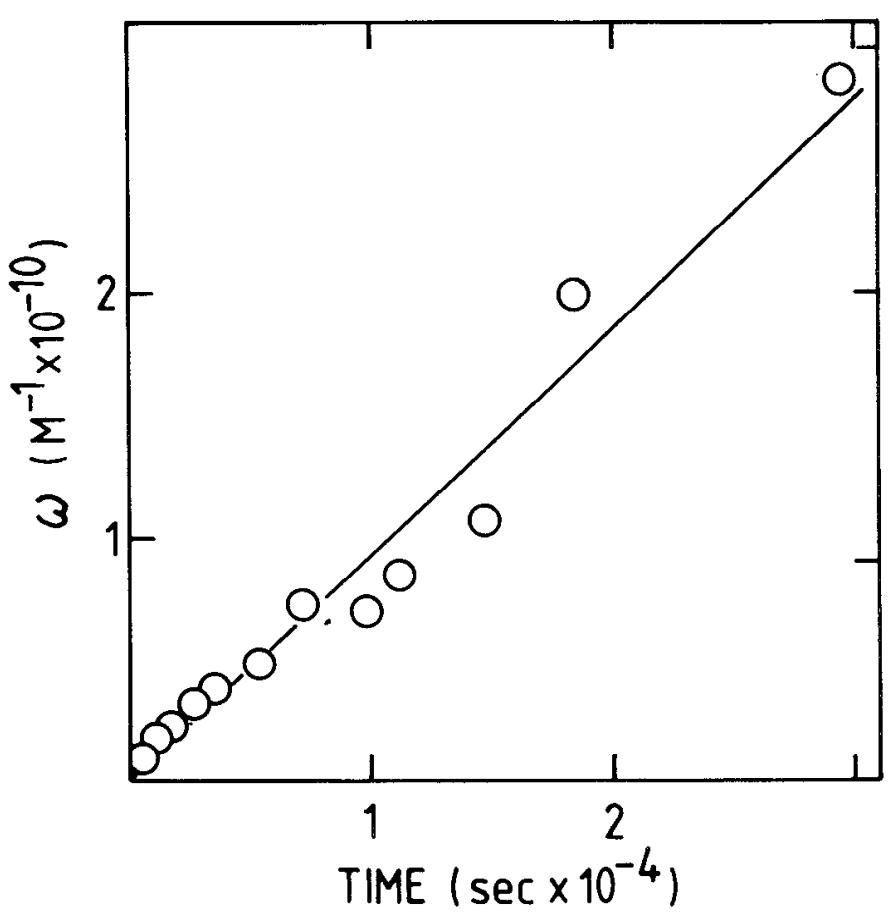

Figure 4. The $4^{\circ} \mathrm{C}$ association rate constant of slow sites in $\mathrm{SH}-\mathrm{SY} 5 \mathrm{Y}$ cells. The data for specific binding to slow sites at $4^{\circ} \mathrm{C}$ (Fig. 2, right) was analyzed using the integrated rate equation for a reversible second-order reaction (Shiu and Friesen, 1974; Stach and Wagner, 1982): $k_{+1} t=(1 /$ $\sqrt{Q}) \ln [\beta(2 x+\gamma) / \gamma(2 x+\beta)]=\omega$, where $Q=D^{2}-4 a b ; \beta=D+\sqrt{Q ;} \gamma=$ $D-\sqrt{Q ;} D-(-\mathrm{a}-\mathrm{b}-\mathrm{c}) ; a=$ initial concentration of ${ }^{125}$ |-NGF $(0.1 \mathrm{nM})$; $b=$ initial concentration of binding sites $(2.9 \mathrm{fmol} / \mathrm{ml}) ; c=\left(a-x_{e}\right)\left(b-x_{e}\right) /$ $x_{e} ; x_{e}={ }^{125}$-NGF bound at equilibrium; $t=$ time (seconds); and $x={ }^{125} \mathrm{I}-\mathrm{NGF}$ specifically bound at time $t(\mathrm{fmol} / \mathrm{ml})$. The plot of $\omega$ versus $t$ is shown; the slope yields $k_{+1}$.

simple shift down in temperature resulted in loss of about $50 \%$ of the total binding over a period of about $30 \mathrm{~min}$, after which a lower plateau in binding was observed. Since slow sites account for only
$10 \%$ of total binding, the loss was most likely from the fast sites, possibly as a result of a decreased affinity at the lower temperature.

In contrast to MC-IXC cells, loss of binding in SH-SY5Y cells was monophasic. When studied by the method of infinite solution plus chase (Fig. 7, right), the half-time of loss at $37^{\circ} \mathrm{C}$ was about $35 \mathrm{~min}$, in this and in other experiments. At $4^{\circ} \mathrm{C}$, the rate of loss was very slow. Loss of binding was studied at a time when attenuation was essentially complete (Fig. 2). When the rate of loss was studied by the method of chase alone, there was also no evidence of the presence of fast sites (not shown). In that type of experiment, the continuous noncompetitive biding shown in Figure 2, left, contributed such that the initial decline in total binding in the presence of chase was eventually followed by a constant rate increase in binding (not shown). Subtraction of the constant rate (Fig. 2, solid squares) noncompetitive component from total binding gave rates of loss consistent with those determined by the method of infinite dilution plus chase. Thus, the monophasic loss rate of binding in SH-SY5Y cells was consistent with the presence of only slow sites.

It is evident that the assay for fast and slow site binding is justified because, in the assay (chase at $4^{\circ} \mathrm{C}$ for $10 \mathrm{~min}$ ), there is complete dissociation of fast site binding but negligible loss of binding from slow sites.

Displacement of ${ }^{125} / \mathrm{NGF}$ binding in SH-SY5Y and in MC-IXC cells. Competitive displacement studies suggest that the slow sites are high affinity and the fast sites are lower affinity sites. In SH-SY5Y cells, there was a two-step displacement of ${ }^{125}$ I-NGF binding (Fig. $8 A$ ). Binding to slow siles was reduced about $50 \%$ at $0.18 \mathrm{~nm} \mathrm{NGF}$, and displacement was complete at about 3 nM NGF. At extremely high concentrations of NGF, a small amount of additional binding could be displaced from what we have defined as "noncompetitive" binding sites in these studies. Since fast sites are absent, noncompetitive binding was defined at $10 \mathrm{nM}$ NGF in SH-SY5Y cells, a concentration that displaces all binding from the slow sites but not from the very low affinity "noncompetitive" constant rate binding previously described (Fig. 2).

In contrast to the value for slow sites in SH-SY5Y cells, the halfmaximal displacement from fast siles (Fig. 8B, open circles) in MCIXC cells was at $3 \mathrm{nM} \mathrm{NGF}$, and complete displacement was at about $300 \mathrm{~nm}$ NGF (Fig. 8B). Thus, the fast sites are of about an
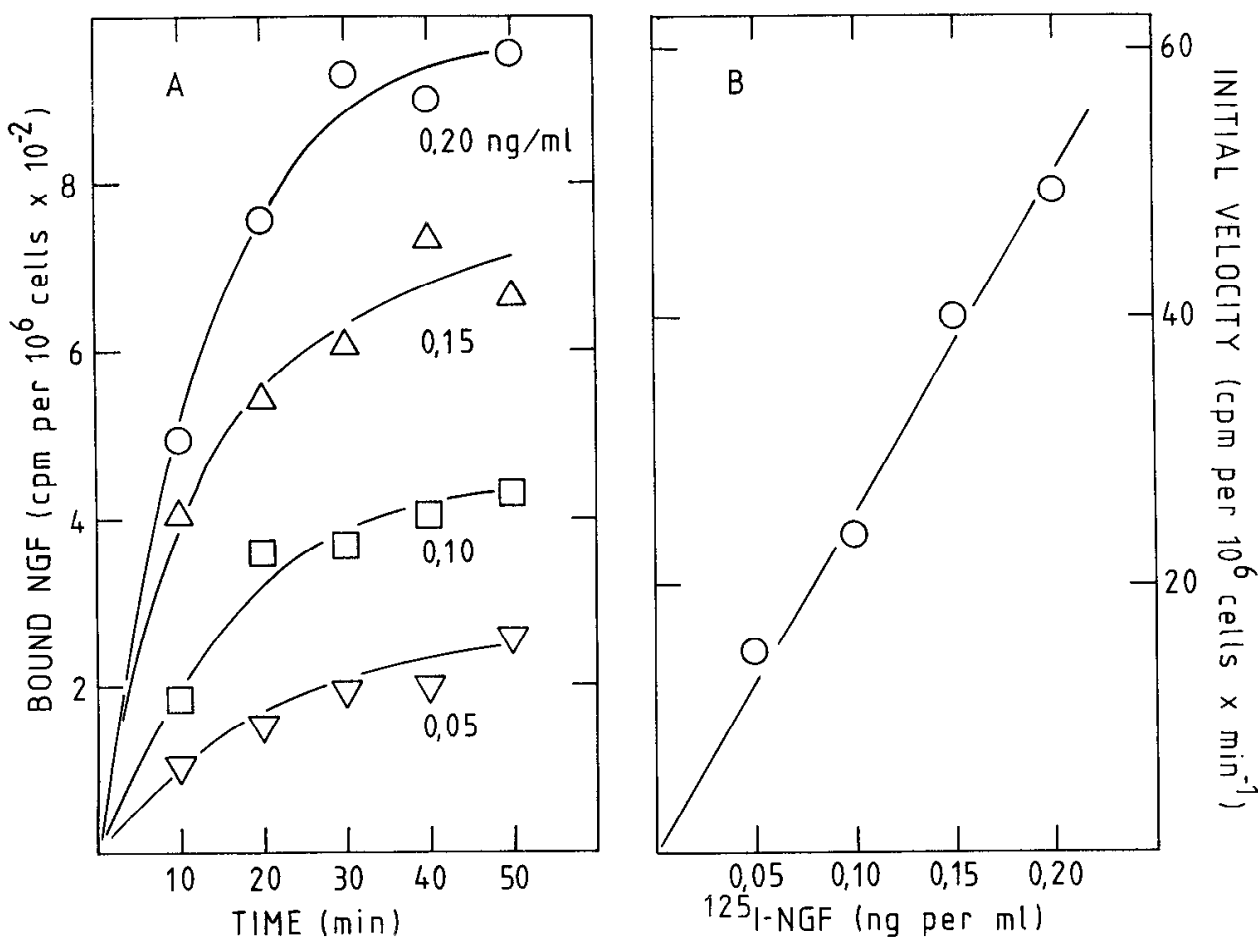

Figure 5. The $37^{\circ} \mathrm{C}$ association rate constant of slow sites in PC12 cells. $A$, The $37^{\circ} \mathrm{C}$ time course of binding to specific slow sites with $0.05(2 \mathrm{pM}), 0.10(4 \mathrm{pM}), 0.15(6$ $\mathrm{pM})$, and $0.20(8 \mathrm{pM}) \mathrm{ng} / \mathrm{ml}$ of ${ }^{125}$-NGF. The noncompetitive binding has been subtracted and was determined in parallel incubation is conlaining, in addition, $400 \mathrm{~nm}$ NGF. $B$, Plot of $V_{0}$ versus ${ }^{125}$-NGF concentration. 


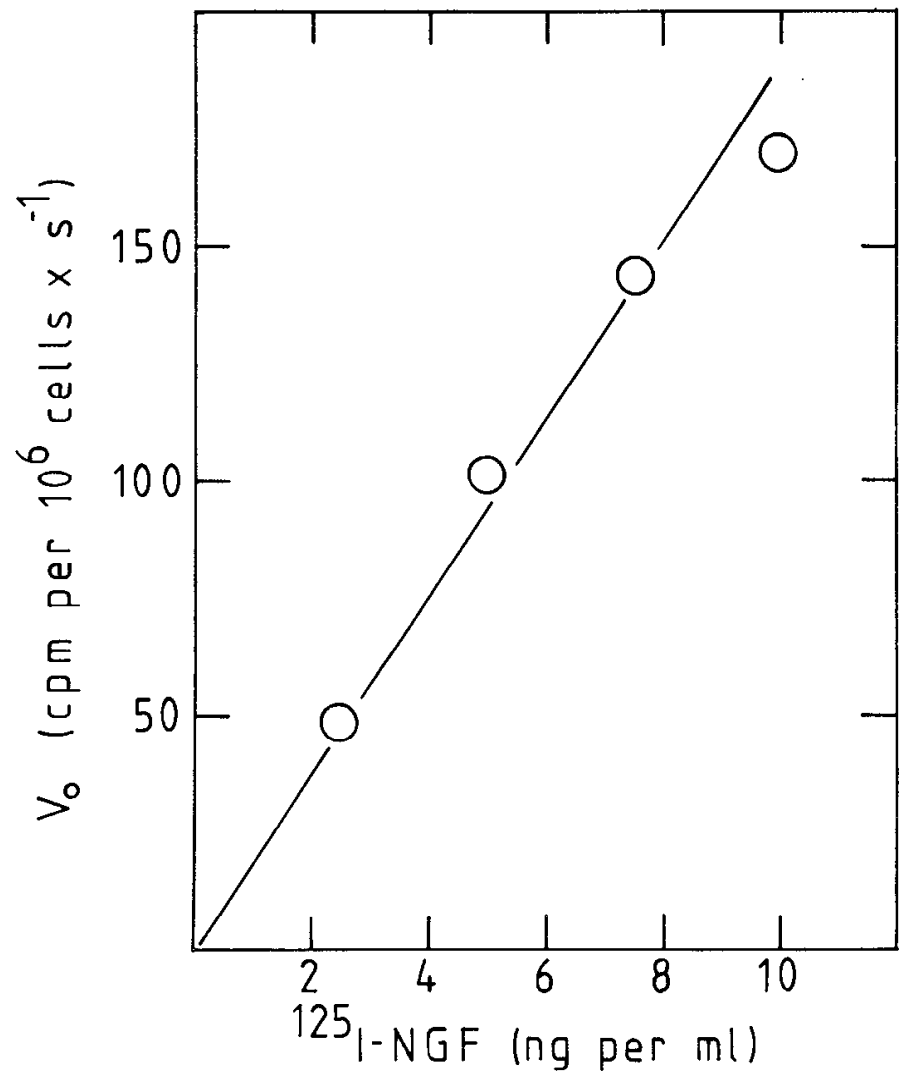

Figure 6. The $37^{\circ} \mathrm{C}$ association rate constant of fast sites in $\mathrm{PC} 12$ cells. The time course of specific fast site binding was determined with the four indicated concentrations of ${ }^{125}$-NGF. The plot of $V_{0}$ versus ${ }^{125}$-NGF concentration is shown.

order of magnitude lower affinity than slow sites. From the plot of residual binding (Fig. 8 , solid circles), it can be seen that the halfmaximal displacement of slow site binding in MC-IXC cells was at about $0.2 \mathrm{nM}$, and displacement from the low affinity "noncompetitive" sites occurred at very high NGF concentrations. Thus, except for the additional displacement of fast sites in MC-IXC, the results were similar to those in SH-SY5Y cells. Although $10 \mathrm{nM}$ NGF is sufficient to displace all specific binding in SH-SY5Y cells, it is insufficient in MC-IXC cells because of the additional presence of the lower affinity fast sites, and $400 \mathrm{~nm}$ was used to define the level of noncompetitive binding in the latter cell line. Under these conditions, the competitive displacement studies of Figure 8 tend to overestimate the true $K_{d}$ value (Jacobs et al., 1975).

Relationship between ${ }^{125} / \mathrm{NGF}$ concentration and binding at $4^{\circ} \mathrm{C}$ in SH-SY5Y and MC-IXC cells. The displacement curves and the rates of loss of binding suggest that the slow sites are high affinity and the fast sites are lower affinity binding sites. Another indication that this is so can be obtained from Scatchard plots of binding at $4^{\circ} \mathrm{C}$, a condition under which secondary binding events are either eliminated or greatly reduced.

The Scatchard plot of total specific binding in SH-SY5Y was linear and consistent with the presence of a single class of specific sites with apparent $K_{d}$ of about $0.22 \mathrm{nM}$ (Fig. 9A). There seemed to be about 580 sites/cell. The Scatchard plot of specific binding to fast sites in MC-IXC is shown in Figure $9 B$. The plot was linear and there appcared to be about 160,000 sites/cell with apparent $K_{d}$ of about $2.9 \mathrm{~nm}$. In contrast, the Scatchard plot of total specific binding in $\mathrm{MC}-\mathrm{XXC}$ cells was curvilinear and was consistent with the presence of two types of sites (data not shown). Curvilinear Scatchard plots of total ${ }^{125}$-NGF binding have been observed in preparations from peripheral neurons (Frazier et al., 1974). In agreement with the displacement data (Fig. 8), at $4^{\circ} \mathrm{C}$ the affinity of slow sites was about an order of magnitude higher than that of fast sites.

Effect of trypsin on the distribution of ${ }^{125} /$ NGF binding in MC$I X C$ and $P C 12$ cells. To further test whether ${ }^{125}$-NGF binding to fast sites is a prerequisite for its binding to slow sites, MC-IXC and PC12 cells were exposed to trypsin prior to incubation with ${ }^{125}$-NGF (Table 1). Treatment with trypsin resulted in complete loss of fast sites in MC-IXC cells. Despite the complete loss, the cells retained $40 \%$ of the initial binding capacity of slow sites. The slow sites, although resistant, nevertheless do lose some activity following exposure to trypsin. This is clear because there is some loss of slow sites on treatment of SH-SY5Y cells with tryspin under these conditions. Therefore, the remaining binding capacity of slow sites in MC-IXC cells, even if corrected for the loss of slow sites based on SH-SY5Y
Figure 7. Rate of loss of bound ${ }^{125}$-NGF at $37^{\circ} \mathrm{C}$ and $4^{\circ} \mathrm{C}$ in MC-IXC and SH-SYSY cells. Left, MC-IXC cells were incubated at $37^{\circ} \mathrm{C}$ for $30 \mathrm{~min}$ with $0.1 \mathrm{nM}{ }^{125}$ - NGF and then treated as follows: $37^{\circ} \mathrm{C}$ without additions (O); $4^{\circ} \mathrm{C}$ without additions $(\square) ; 37^{\circ} \mathrm{C}$ plus $400 \mathrm{nM}$ NGF (O); and $4^{\circ} \mathrm{C}$ plus $400 \mathrm{nM}$ NGF ( $\square$ ). Right, SH-SY5Y cells were incubated at $37^{\circ} \mathrm{C}$ for $4 \mathrm{hr}$ with $0.1 \mathrm{~nm}^{125}$-NGF, cooled in ice, collected by low speed centrifugation, and resuspended in ${ }^{125}$-NGF-free medium at a dilution factor greater than 27,500. NGF (10 nM) was added, and the cells were incubated at $37^{\circ} \mathrm{C}(\boldsymbol{)})$ or $4^{\circ} \mathrm{C}(\square)$. The best fit lines were determined by linear regression. Noncompetitive binding has been subtracted.
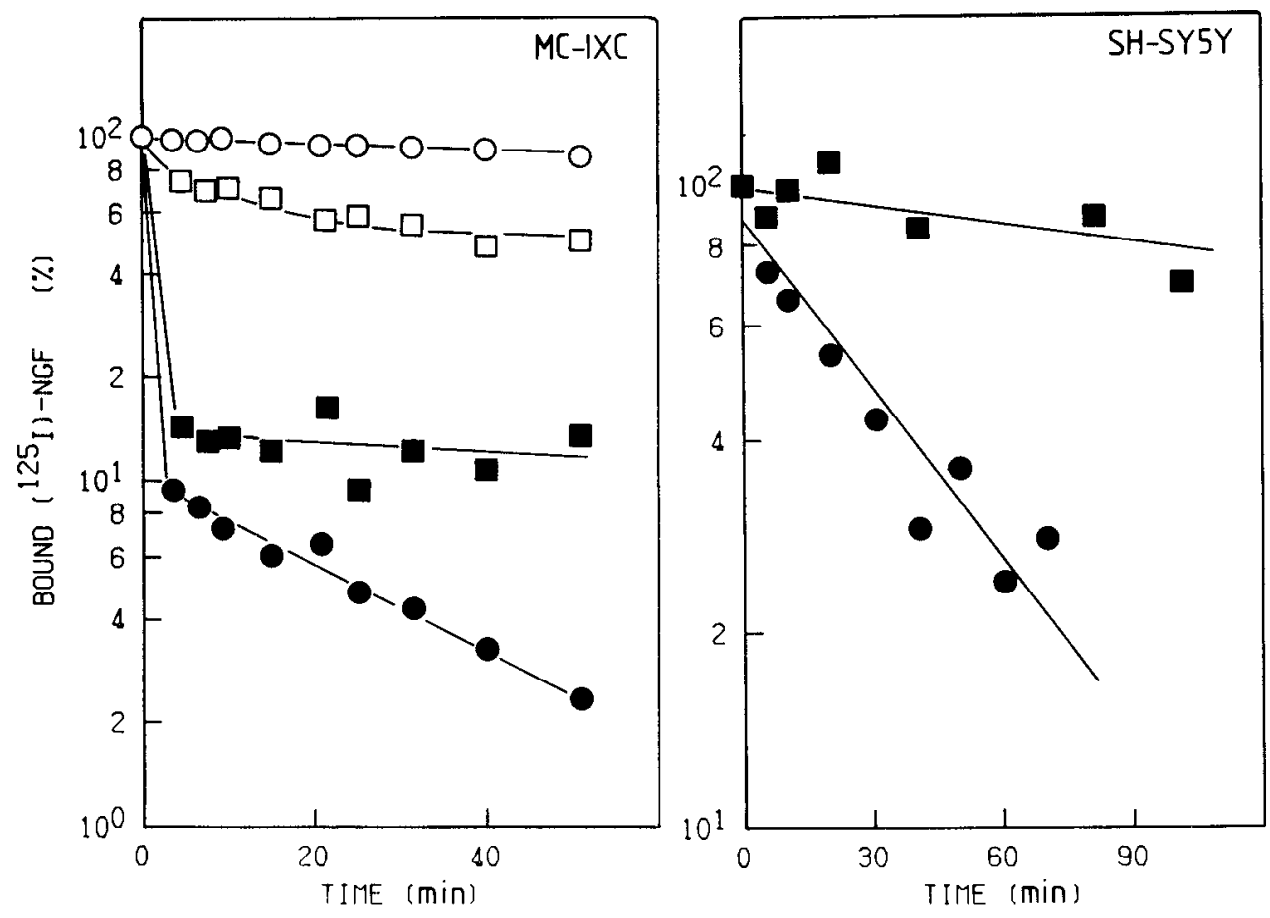


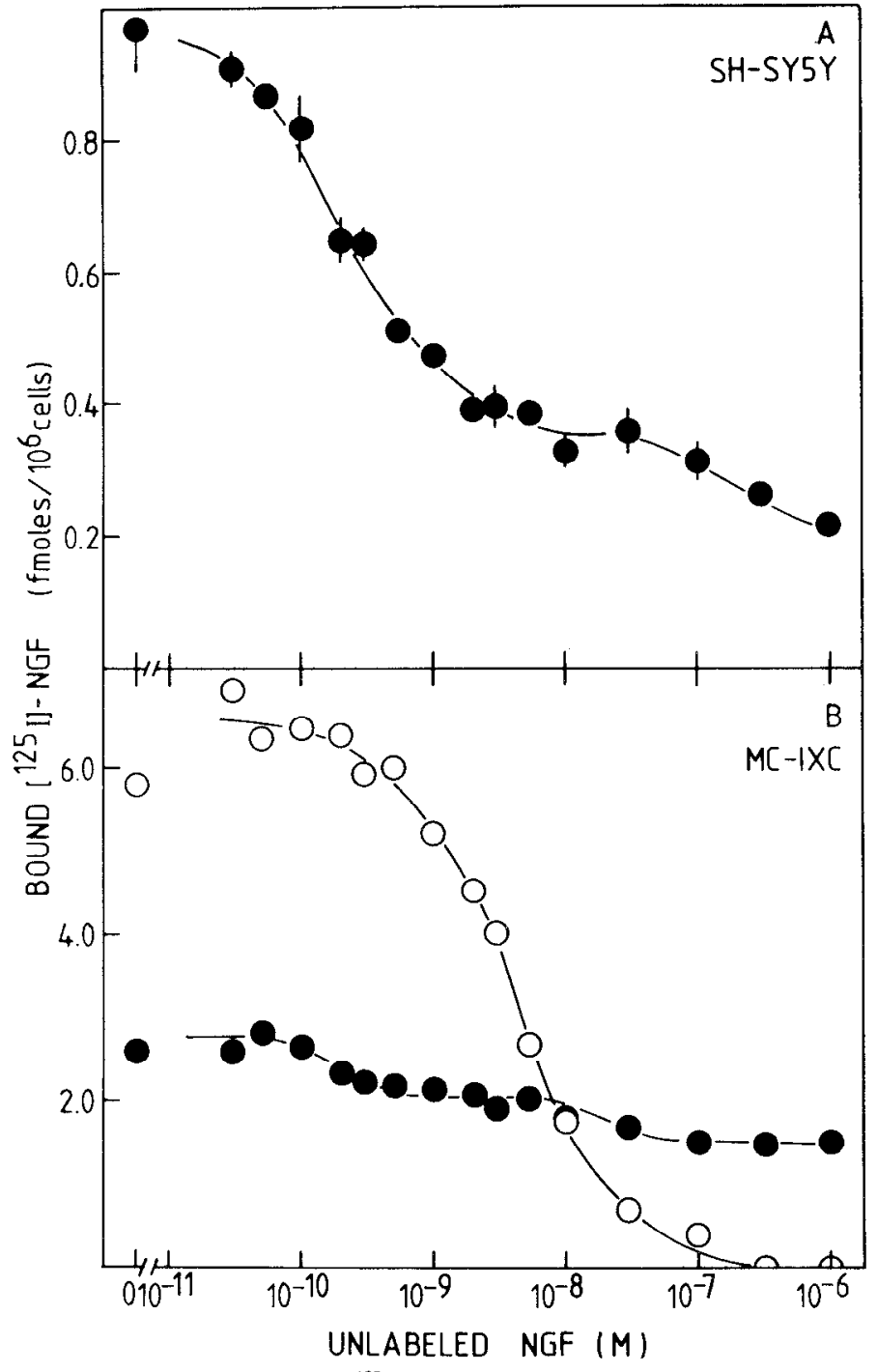

Figure 8. Displacement of ${ }^{125}$-NGF binding in SH-SY5Y cells and in MCIXC cells. Cells were incubated for $2 \mathrm{hr}$ at $37^{\circ} \mathrm{C}$ with $0.1 \mathrm{nM}{ }^{125}$-NGF alone and with various concentrations of competing unlabeled NGF as shown. $A$, Displacement of total binding in SH-SY5Y cells. $B$, Displacement of binding in MC-IXC cells: (O), fast sites; $(\odot)$, residual binding. Values are means and $\mathrm{SD}(N=4$ replicate assays). Note the scale difference in $A$ and $B$.

cells, must represent a high efficiency for binding to slow sites in the absence of fast sites

Alternatively, it was possible that, following exposure to trypsin, there is rapid synthesis of new fast sites which are converted to slow sites by NGF. This alternative explanation is unlikely to be correct. Binding to the slow sites in trypsin-treated cells is efficient even at $4^{\circ} \mathrm{C}$ and in $2 \mu \mathrm{g} / \mathrm{ml}$ of cycloheximide at $37^{\circ} \mathrm{C}$ (not shown), separate conditions in which the rate of protein synthesis is greatly reduced. Cycloheximide $(2 \mu \mathrm{g} / \mathrm{ml})$ does substantially reduce $[3 \mathrm{H}]$ leucine incorporation into the trichloroacelic acid-insoluble fraction under these conditions (Recio-Pinto and Ishii, 1984).

In PC12 cells, trypsin treatment resulted in loss of $88 \%$ of the fast site binding capacity, but only $38 \%$ of the binding capacity of slow sites (Table I). The results in PC12 cells, then, were in agreement with our data indicating that the presence of fast sites is not required for binding of ${ }^{125} \mathrm{~J}$-NGF to slow sites in NB cells.

Transfer of ${ }^{225}$-NGF from fast to slow sites in PC12 cells. Landreth and Shooter (1980) have reported that ${ }^{125}$-NGF initially bound to fast sites in PC12 cells may be directly transferred to slow sites. Direct transfer is an important observation supporting the conversion hypothesis.
We decided to study the nature of the transfer process in $\mathrm{PC} 12$ cells (Fig. 10). The ceils were incubated for 2 min at $37^{\circ} \mathrm{C}$ with ${ }^{125}$ NGF. Thereafter, the cells were collected and resuspended in media free of ${ }^{125}$-NGF, and the transfer process was studied. The amount of ${ }^{125}$-NGF bound to fast sites at zero time in this type of experiment, because of the fast dissociation rate, would be dependent on the factors that affect the rapid redistribution of ${ }^{125}$-NGF between the fast sites and the media. Upon continuation of incubation, there was an increase in binding to slow sites and loss of binding from fast sites. Thus, we replicated the essential observation of Landreth and Shooter (1980), and this kind of data could suggest direct transfer of bound radioactivity from fast to slow sites through a conversion process. Alternatively, the radioactivity "transferred" to slow sites could have been from the media, potentially derived from two separate sources. One source is simply residual radioactivity trapped in the cell pellet and adhered to the vessel walls. The other source is radioactive NGF released from fast sites, freed for rebinding. Released ${ }^{125}$ I-NGF can be rebound by sensory (Sutter et al., 1979) and PC12 (Calissano and Shelanski, 1980) cells.

To try to distinguish between direct transfer and uptake from the media, we also studied whether the increase in binding to slow sites could occur in the presence of excess NGF. Excess NGF would not interfere with direct transfer, because bound ${ }^{125}$-NGF would not be released during conversion from fast to slow sites. However, excess NGF would effectively compete for uptake of ${ }^{125} \mathrm{I}$-NGF from the media. In the presence of excess NGF, an increase in binding to slow sites was not observed (Fig. 10). instead, there was a gradual decline in the amount of ${ }^{125}$ I-NGF initially bound to the slow sites, entirely expected as the normal loss of bound radioactivity following the addition of excess NGF. These results show that ${ }^{125}$ I-NGF initially bound to fast sites is not directly transferred to slow sites. This assumes conversion is highly efficient. The analysis when conversion may be inefficient will be discussed later. Also, the results show that, despite the large dilution factor, significant amounts of ${ }^{125}$ I-NGF can be available in the media for binding in this type of experiment.

Distribution of fast and slow sites in several human NB cell lines. There is heterogeneity in the neurite outgrowth response to NGF among human NB cell lines that are established from different NB tumors (Sonnenfeld and Ishii, 1982; Recio-Pinto and Ishii, 1984). Binding of ${ }^{125}$ I-NGF was studied in several human NB cell lines to determine whether the heterogeneity in response was correlated with a specific distribution pattern of fast and slow sites.

Specific binding was detected in all cell ines (Table II). Fast sites were present only on $\mathrm{N}^{-}$SK-N-MC and its subclone MC-IXC. Slow sites were detected on all of the lines studied. IMR-32 requires high concentrations of NGF for neurite formation (Reynolds and PerezPolo, 1981; Sonnenfeld and Ishii, 1982), and it had only slow sites. Other experiments revealed that only slow sites could be detected on $\mathrm{N}^{-} \mathrm{CHP}-100$ and on $\mathrm{N}^{+} \mathrm{SK}-\mathrm{N}-\mathrm{SH}$ cells (data not shown). Thus, in three $\mathrm{N}^{+}$cell lines (SK-N-SH, SH-SY5Y, and LA-N-5), fast sites were undetectable, showing that binding of ${ }^{125}$ I-NGF to fast sites is not required for neurite outgrowth. Because slow sites were present in all cell lines, unresponsiveness by neurite outgrowth in some lines was due to causes other than the absence of this type of site.

\section{Discussion}

Relationship of low and high affinity sites to NGF actions in sensory and sympathetic neurons. The presence of two types of sites in sensory (Sutter et al., 1979; Olender et al., 1981) and sympathetic (Olender and Stach, 1980) cells has made difficult the assignment of a particular site as the receptor regulating given responses to NGF. The tight binding and the inability of other polypeptides to compete for binding of ${ }^{125}$-NGF are properties which suggest that these sites are receptors, but do not entirely exclude the possibility that they are specific transport or degradative sites. The modification of NGF by exposure to bromosuccinimide (Banerjee et al., 1973; Cohen et al., 1980), and complex formation of NGF with its monoclonal antibodies (Zimmermann et al., 1981), can 
Figure 9. Relationship between ${ }^{125}$-NGF concentration and binding at $4^{\circ} \mathrm{C}$ to slow sites in SH-SY5Y cells and fast sites in MC-IXC cells. In A, SH-SY5Y cells were incubated for $7 \mathrm{hr}$ at $4^{\circ} \mathrm{C}$ with various concentrations of ${ }^{125} \mathrm{I}-\mathrm{NGF}$. Noncompetitive binding was determined in parallel incubations. The inset shows the saturation isotherm of specifically bound ${ }^{125}$ - NGF to slow sites, and the figure shows the Scatchard plot of the data. $B, \mathrm{MC}-\mathrm{IXC}$ cells were incubated for $2 \mathrm{hr}$ at $4^{\circ} \mathrm{C}$. The inset shows the saturation isotherm of specifically bound ${ }^{125}$-NGF to fast sites, and the figure shows the Scatchard plot.

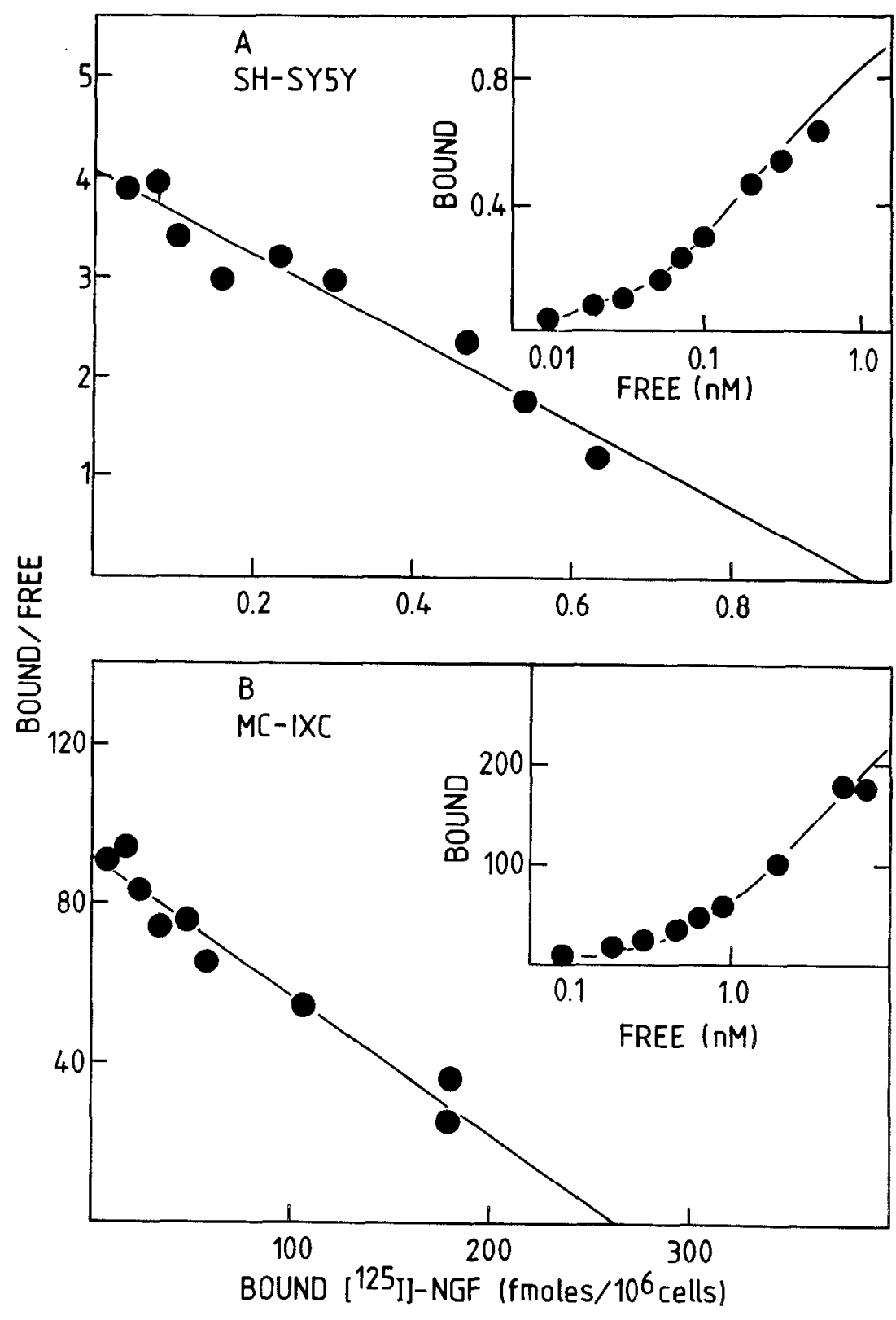

TABLE ।

Effect of trypsin on the distribution of ${ }^{125} /$-NGF binding in MC-IXC and PC12 cells

The cells were incubated with and without $0.125 \%$ trypsin at $37^{\circ} \mathrm{C}$ for 8 min. Soybean trypsin inhibitor $(1 \mathrm{mg} / \mathrm{ml})$ and $10 \%$ serum were added to terminate the reaction, and cells were collected. The cells were resuspended in fresh medium containing $0.2 \mathrm{nM}{ }^{125}$-NGF and soybean trypsin inhibitor (1 $\mathrm{mg} / \mathrm{ml})$, and were incubated for $2 \mathrm{hr}$ at $37^{\circ} \mathrm{C}$. The cells were counted and binding to fast and slow sites was assayed

\begin{tabular}{cccc} 
Cell Line & Trypsin & \multicolumn{2}{c}{ Specifically Bound ${ }^{125} \overline{\text {-NGF }}{ }^{a}\left(\mathrm{cpm} / 10^{6}\right.$ cells $)$} \\
\cline { 3 - 4 } MC-IXC & - & $1669 \pm 59(100)^{b}$ & $6549 \pm 125(100)$ \\
& + & $671 \pm 77(40)$ & Sast \\
PC12 & - & $4248 \pm 66(100)$ & $2091 \pm 86(100)$ \\
& + & $2636 \pm 31(62)$ & $250 \pm 35(12)$ \\
\hline
\end{tabular}

${ }^{a}$ Values are means \pm SE ( $N=4$ replicate assays).

${ }^{b}$ Values in parentheses, percentages relative to results in untreated controls. prevent the binding of NGF to the high and low affinity sites and the neurite outgrowth response. These studies do not exclude the possibility that the true NGF receptor which modulates neurite outgrowth is neither of these sites, since modified or complexed NGF may fail to bind to the other kinds of sites as well as to the receptors. The observation that certain tumor promoters, such as saccharin, can reversibly inhibit both ${ }^{125}$-NGF binding and the neurite elongation response (Ishii,1982a, b), suggests that at least one of these two sites is indeed a receptor for neurite formation. Neither the NGF modification and complex formation studies nor the antagonism studies reveal which site is the receptor, because, in each of these studies, binding to both high and low affinity sites was inhibited.

The high affinity sites may be the receptors for neurite outgrowth. A naturally occurring 2.5-fold decrease in the number of lower affinity sites in one strain of White Leghorn chick embryos has no apparent effect on neurite outgrowth (Stach and Wagner, 1982). The $K_{d}$ value of the high affinity sites (Sutter et al., 1979; Olender et al., 1981) is estimated as having about the same value as the NGF concentration causing the half-maximal neurite outgrowth response in sensory neurons (Ishii, 1978). At that concentration only a small fraction of 


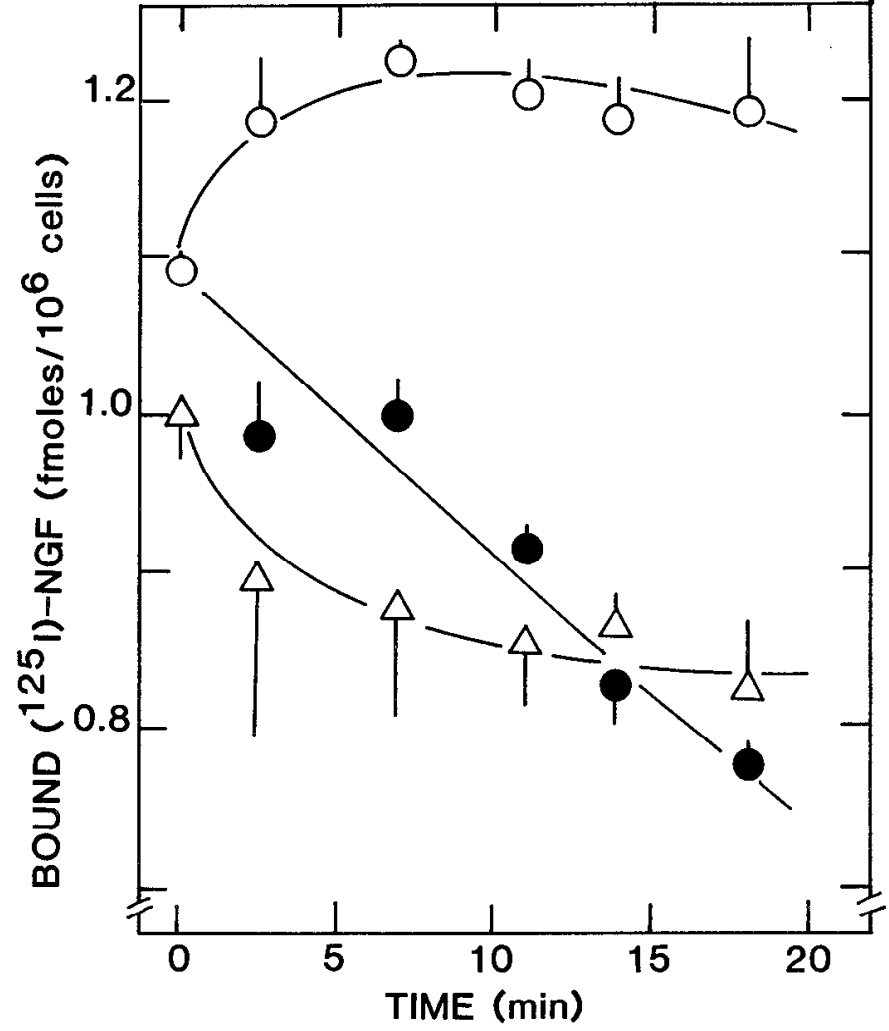

Figure 10. Effect of excess NGF on redistribution of ${ }^{125}$-NGF to fast and slow sites in $\mathrm{PC} 12$ cells. The cells were incubated at $37^{\circ} \mathrm{C}$ with $40 \mathrm{pm}^{125}$ NGF for $2 \mathrm{~min}$. The cells were centrifuged at $800 \times g$ for $1 \mathrm{~min}$ and resuspended in the same volume of warm media that were free of ${ }^{125}$-NGF. The cells were incubated further at $37^{\circ} \mathrm{C}$ with and without $4 \mathrm{nM} \mathrm{NGF}$. At various times, binding to fast and slow sites was assayed. Only specifically bound radioactivity is shown. Values are means and $\mathrm{SE}(N=3$ replicate determinations). $\triangle$, fast sites; $O$, slow sites; - slow sites determined in incubations with excess NGF.

\section{TABLE ॥}

Distribution of ${ }^{125}$ /-NGF binding sites in human neuroblastoma cell lines

Condition I, cells were incubated with $0.4 \mathrm{nM}$ 125.-NGF and then assayed for binding by the equilibrium sedimentation method. Condition II, cells were incubated with $0.1 \mathrm{~nm}{ }^{125}$-NGF and then assayed for binding by the sucrose density method. Only specific binding is shown. Values are means \pm SD $(N$ $=4$ replicate assays)

\begin{tabular}{cccc}
\hline Cell Line & \multicolumn{2}{c}{ Bound ${ }^{125}$-NGit (tmol/10 cells) } & $\begin{array}{c}\text { Neurite } \\
\text { Outgrowth }\end{array}$ \\
\cline { 3 - 3 } Condition I & Slow & Fast & \\
IMR-32 & $2.87 \pm 0.92$ & 0 & + \\
SK-N-MC & $4.06 \pm 0.91$ & $8.16 \pm 1.34$ & - \\
MC-IXC & $3.67 \pm 0.45$ & $10.20 \pm 0.73$ & - \\
SH-EP & $2.11 \pm 0.84$ & 0 & - \\
Condition II & & & \\
CHP-134 & $0.41 \pm 0.06$ & 0 & - \\
LA-N-5 & $0.60 \pm 0.06$ & 0 & + \\
\hline
\end{tabular}

${ }^{a}$ Data from Sonnenfeld and Ishii (1982); scored as unresponsive (-) and responsive (+).

${ }^{b}$ Cloned subline.

the low affinity sites is estimated to be occupied (Sutter et al., 1979). Because the low affinity sites are present in numbers at least 10 fold larger than the high affinity sites (Sutter et al., 1979; Claude et al., 1982), that fraction may, nevertheless, be significant in terms of the absolute number of low affinity sites occupied. A spare receptor system (Stephenson, 1956) might be involved, in which casc a maximum response is attainable with occupancy of only a fraction of available sites. Thus, the relative importance of high and low affinity sites to neurite outgrowth in sensory and sympathetic neurons is not yet fully established.

Relationship of fast and slow sites to NGF actions in human NB cells. Only slow sites are detectible in SH-SY5Y cells (Figs. 2 and $8 A$; Sonnenfeld and Ishii, 1982), indicating that occupancy of fast sites in human NB cells is not required for enhancement of neurite formation (Perez-Polo et al., 1979; Sonnenfeld and Ishii, 1982) or other demonstrated actions of NGF in these cells, such as increased protein synthesis (Sonnenfeld and Ishii, 1982; Spinelli et al., 1982) and veratridine-dependent $\mathrm{Na}^{+}$uptake (Perez-Polo et al., 1979). However, the absence of fast sites cannot prove simply by default that slow sites are the receptors. Recent observations show that the slow sites are very likely the receptors for neurite outgrowth in human NB cells. The capacity of SH-SY5Y cells to respond by neurite formation to NGF can be activated and inactivated by insulin in parallel with the capacity of slow sites to bind NGF (Recio-Pinto et al., 1984).

The relationship of the slow sites to other actions of NGF is less clear. For example, unlike the sensory, sympathetic, chromaffin, and PC12 cells, a requirement of NGF for human NB cell survival was not found (Sonnenfeld and Ishii, 1982). Also, unlike in PC12 cells (Greene and Tischler, 1976), NGF does not cause growth inhibition in human NB cells (Sonnenfeld and Ishii, 1982).

Slow sites are present in $\mathrm{N}^{-}$lines such as MC-IXC, CHP-100, and CHP-134 (Table II), showing that the $\mathrm{N}^{-}$phenotype in these cells is due to factors other than absence of this type of site. CHP-100 and CHP-134 are unresponsive by neurite outgrowth to other agonists in $\mathrm{N}^{+}$cell lines, such as tumor promoters (Spinelli et al., 1982). Because the tumor promoter receptors are present (Spinelli and Ishii, 1983), the lesions are suggested to be at sites distal to the NGF and tumor promoter receptors in these cell lines.

The role of fast sites in MC-IXC cells is unclear. Fast sites, but not slow sites, are present on non-neuronal as well as neuronal cells (Sutter et al., 1979; Carbonetto and Stach, 1982; Buxser et al., 1983).

Properties of fast and slow ${ }^{125}$-NGF binding siles in human NB cells. The $37^{\circ} \mathrm{C} K_{d}$ value can be calculated. The half-time of loss of binding was 25 to 30 min for slow sites (Fig. 7 , right). This value was the same as that obtained when dissociation was studied after only 30 min (Recio-Pinto et al., 1984). From the ratio of rate constants, the $K_{\mathrm{d}}$ value of $4 \times 10^{-11} \mathrm{M}$ was calculated, which corresponds closely to the equilibrium binding value of $5.7 \times 10^{-11} \mathrm{M}$ by Lyons et al. (1983) in extracted sites. This type of calculation is based on the assumption that the rate of loss of binding approximates closely the true dissociation rate. To what extent the rate of loss of binding includes other events, such as cycling involving internalization or other receptor processing steps, is not known. The $4^{\circ} \mathrm{C}$ apparent $K_{d}$ value of slow sites was about 0.22 nM (Fig. 9A). The half-maximal neurite outgrowth response in $\mathrm{SH}-\mathrm{SY} 5 \mathrm{Y}$ cells is at $0.2 \mathrm{nM}$ (Sonnenfeld and Ishii, 1982). The lower affinity and sensitivity compared to other cell types may reflect a species difference in binding and response to mouse NGF. The $37^{\circ} \mathrm{C}$ association rate constants of fast and slow sites are about the same (Fig. 3). The slow sites are trypsin resistant (Table I) and of high affinity (Figs. 7 to 9 ), and loss of binding readily occurs at $37^{\circ} \mathrm{C}$ but only very slowly at $4^{\circ} \mathrm{C}$ (Fig. 7). The fast sites are trypsin sensitive and of low affinity, and dissociation is rapid at both $37^{\circ} \mathrm{C}$ and $4^{\circ} \mathrm{C}$. These properties are shared with the slow and fast sites in PC12 cells and the high and low affinity sites in sensory neurons, respectively.

Temperatures near $4^{\circ} \mathrm{C}$ inhibit endocytosis of polypeptides bound to their receptors in other cell systems (Carpenter and Cohen, 1976; Goldstein et al., 1979). The slow sites are observable at $4^{\circ} \mathrm{C}$ (Figs. 1,2 , and 9), and their distinguishing features are unlikely to be due to endocytosis. In fact, the differences in the rates of loss of binding and the sensitivity to trypsin are properties retained by fast and slow sites following extraction from melanoma cell mombranes (Buxser et al., 1983). 
Fast and slow sites are attenuated at $37^{\circ} \mathrm{C}$ in human NB cells (Figs. 1 and 2). Attenuation of slow sites is observed in two $\mathrm{N}^{+}$but not in three $\mathrm{N}^{-}$cell lines, suggesting that secondary binding events may be different in $\mathrm{N}^{-}$cell lines. The equilibrium binding parameters can be obtained following preincubation of cells for $1 \mathrm{hr}$ at $37^{\circ} \mathrm{C}$ prior to addition of ligand, which can eliminate slow site attenuation (Recio-Pinto et al., 1984).

NGF-mediated conversion of fast to slow sites. The following points indicate that NGF-mediated conversion of fast to slow sites, of the type shown in formula 1, is unlikely to occur in human NB cells. (1) ${ }^{125} \mathrm{I}-\mathrm{NGF}$ can bind to slow sites in SH-SY5Y and other human NB cell lines despite the absence of detectible fast sites (Fig. 2. Table II; Sonnenfeld and Ishii, 1982). It is improbable that a rapid conversion prevented the detection of fast sites at $37^{\circ} \mathrm{C}$ because they were not detected even when the rate of binding and putative conversion to slow sites were greatly reduced at $4^{\circ} \mathrm{C}$ (Fig. 2, right). Moreover, the much fewer sites in SH-SY5Y compared to MC-IXC cells means that the rate of site occupancy would be slower, as, in fact, is observed (Figs. 1 and ?). In turn, the rate of conversion should be slower, providing a greater opportunity for detection of fast sites in SH-SY5Y cells, were they present. (2) Despite the complete elimination of fast sites on MC-IXC cells following exposure to trypsin, the mostly remaining slow sites could bind ${ }^{125}$ /-NGF (Table 1). The results served to show that fast and slow sites are present prior to addition of NGF. (3) in conversion (formula 1), the association kinetics of slow sites would be dependent on the amount of [NGF*Fast] complexes formed. Instead, the kinelics were consistent with a bimolecular reaction at $4^{\circ} \mathrm{C}$ (Fig. 4). This is also the case for binding to the high affinity sites at $37^{\circ} \mathrm{C}$ in sensory neurons (Sutter et al., 1979). (5) The curve for the time course of slow site binding should be sigmoidal in shape in conversion (formula 1), because the concentration of [NGF* Fast] complexes is small at early times and the rate of conversion would increase with the accumulation of such complexes over time. However, a lag in the time course of binding to slow sites was not detected, and the hyperbolic binding curves appeared to pass through the origin (Figs. 1 to 3). Our earliest data are at $2.5 \mathrm{~min}$ (Fig. $3 \mathrm{~A}$ ) and do not rule out the possibility of a 30- to 60-sec lag phase as seen by Landreth and Shooter (1980)

At $0.1 \mathrm{~nm}{ }^{125}$-NGF there is a quicker rate of development of binding to fast as compared to slow sites (Figs. 1 and 2). This is expected because fast sites are much more numerous than slow sites (Fig. 9), and site density helps to drive binding. Thus, the quicker development of binding to fast sites is not necessarily indicative of conversion. It would be difficult to argue that attenuation of fast sites is due to conversion of fast to slow sites in MC-IXC cells, because conversion to higher affinity binding should not in itself cause a decrease in the total amount of NGF bound (Fig. 1). Rather, binding should either remain the same or increase.

The PC12 cell merits separate discussion since most of the data supporting the possibility for NGF-mediated conversion have been developed in that system. Consider a model of NGF-mediated conversion of the type shown below:

$$
\mathrm{NGF}+\mathrm{Fast} \underset{k-1}{\stackrel{k_{+1}}{\rightleftharpoons}}\left[\mathrm{NGF}^{\star} \mathrm{Fast}\right] \underset{k-2}{\stackrel{k_{+2}}{\rightleftharpoons}}\left[\mathrm{NGF}^{\star} \text { Slow }\right]
$$

Direct transfer of bound ${ }^{125}$-NGF from fast to slow sites would strongly support this model. Landreth and Shooter (1980) have provided data suggestive of direct transfer, and we confirm their observation (Fig. 10). We should recall that $k_{-1}$ is very rapid. Nevertheless, if conversion were efficient, a significant fraction of prebound ${ }^{125}$-NGF should be transferred to slow sites. However, when excess NGF was present, it was clearly demonstrated that prebound ${ }^{125}$ I-NGF could not be directly transferred from fast to slow sites.

Alternatively, the direct transfer might not be observed in PC12 cells in the presence of excess NGF because the conversion process is very inefficient, and only a minor fraction of [NGF*Fast] complexes are converted to [NGF*Slow] complexes. In other words, conversion is partly dependent on the rapid turnover of fast site binding, and the excess NGF added in Figure 10 would obscure conversion. But conversion dependent on rapid turnover of binding also seems unlikely. First of all, the association rate constant of slow sites would have to be much smaller than that of fast sites if conversion were inefficient, and it is not (Figs. 3, 5, and 6). Second, the total turnover would be substantially reduced by the extensive trypsinization of fast sites shown in Table I, and the conversion to slow sites should then be greatly decreased. To the contrary, the observation that binding to slow sites can occur despite a large reduction in fast sites caused by trypsin (Table I; Schechter and Bothwell, 1981) suggests that conversion, if present, has to be relatively cfficient to be able to account for the binding to slow sites. With regard to this point, Yankner and Shooter (1982) suggested that, with the correct titration of tryptic digestion, the number of low affinity receptors can be reduced to a low enough level so that the subsequent binding of NGF might result in the complete conversion of low to high affinity receptors. All of these points indicate that the putative conversion must be an efficient process. Is it possible that the loss of slow site binding on addition of excess NGF could prevent observation of conversion? We feel this is unlikely because the half-time of loss of slow sites is 20 to $30 \mathrm{~min}$. In efficient conversion, almost every fast site would be converted to a slow site, and the accumulation of slow sites has to be as rapid as the loss of fast sites, which is complete within a minute or two. Thus, the effect of dissociation of slow sites should not obscure observation of conversion. Therefore, whatever the fraction of fast sites that are converted to slow sites, the binding to slow sites observed in Figure 10 must arise from the fast sites. However, the results showed that all of the observable increase in binding to slow sites could be inhibited by excess NGF (Fig. 10), and all of the binding to slow sites appears to arise from the media. How then can the slower rate of binding to slow sites be explained? We believe that it is because there are 10-fold fewer slow than fast sites, and the rate (not rate constant) is dependent on the law of mass action.

The association kinetics were consistent with simple bimolecular processes in PC12 cells, and the association rate constants had the same values for both fast and slow siles (Figs. 5 and 6). The high and low affinity sites in sensory neurons (Sutter et al., 1979; Olender et al., 1981), and the fast and slow sites in human NB cells (Fig. 3), likewise share the same $k_{+1}$ values.

Schechter and Bothwell (1981) suggest that fast and slow sites have unequal rate constarits of association in PC12 cells. They did not actually measure the rate constants of association but, rather, the rates at which binding developed to fast and slow sites at a given concentration of ligand. We agree with them that binding to fast sites can develop faster than to slow sites; that is because there are many more fast than slow sites (Schechter and Bothwell, 1981), as discussed above. A lag in binding to slow sites would be consistent with the conversion model and was observed by Landreth and Shooter (1980), but not by Schechter and Bothwell (1981), nor by us (Fig. 5). Other kinds of data bear on this problem. Recently, Vale et al. (1983) reported that fast sites are $M_{r}=100,000$ and slow sites are $M_{r}=160,000$. An example of ligand-mediated receptor conversion in which so substantial an increase in covalent size occurs is unknown to us. In addition, a monoclonal antibody that inhibits NGF binding to fast sites on MC-IXC cells does not inhibit binding to slow sites on SH-SY5Y cells (unpublished results). Thus, when the data in human NB and PC12 cells are considered together, it seems unlikely that NGF-mediated conversion occurs. We believe that NGF binds directly to slow sites.

Hence, at least as strong an alternative interpretation can be advanced to the interesting conversion hypothesis. Neither the results of Landreth and Shooter (1980) nor our own should be considered conclusive. Whatever the outcome, as indicated by a number of recent publications that have included some discussion 
of conversion, there is considerable interest in this important topic, and further study is warranted.

Although NGF-mediated conversion seems unlikely, fast and slow sites may be related in other ways. For example, fast and slow sites may reflect two distinct binding forms of the same gene product. Potentially, the observation that wheat germ agluttinin can increase the number of slowly dissociating sites in melanoma membrane preparations (Buxser et al., 1983) and in intact PC12 cells (Vale and Shooter, 1982) might be evidence for this type of two-state model. Alternatively, fast and slow sites arise as products of separate genes.

\section{References}

Aloe, L., and R. Levi-Montalcini (1979) Nerve growth factor induced transfor mation of immature chromaffin cells in vivo into sympathetic neurons Effect of antiserum to nerve growth factor. Proc. Natl. Acad. Sci. U. S. A 76: $1246-1250$

Banerjee, S. P., S. H. Snyder, P. Cuatrecasas, and L. A. Greene (1973) Binding of nerve growth factor receptor in sympathetic ganglia. Proc. Natl. Acad. Sci. U. S. A. 70: 2519-2523.

Biedler, J. L., L. Helson, and B. A. Spengler (1973) Morphology and growth, tumorigenicity, and cytogenetics of human neuroblastoma cells in continuous culture. Cancer Res. 33: 2643-2652.

Biedler, J. L., S. Roffler-Tarlov, M. Schachner, and L. S. Freedman (1978) Multiple neurotransmitter synthesis by human neuroblastoma cell lines and clones. Cancer Res. 38: 3751-3757

Bradshaw, R. A. (1978) Nerve growth factor. Annu. Rev. Biochem. 47: 191216.

Burmeister, D. W., and K. Lyser (1982) Process formation in the human neuroblastoma clone SK-N-SH-SY5Y in vitro. Diss. Abstr. Int. 43: 1334-B.

Burton, L. E., W. H. Wilson, and E. M. Shooter (1978) Nerve growth factor in mouse saliva. Rapid isolation procedures for and characterization of $7 \mathrm{~S}$ nerve growth factor. J. Biol. Chem. 253: 7807-7812.

Buxser, S. E., D. J. Kelleher, L. Watson, P. Puma, and G. L. Johnson (1983) Change in state of nerve growth factor receptor. J. Biol. Chem. 258 3741-3749.

Calissano, P., and M. L. Shelanski (1980) Interaction of nerve growth factor with pheochromocytoma cells. Evidence for tight binding and sequestration. Neuroscience 5: 1033-1039.

Carbonetto, S., and R. W. Stach (1982) Localization of nerve growth factor bound to neurons growing nerve fibers in culture. Dev. Brain Res. 3: 463473.

Carpenter, G., and S. Cohen (1976) ${ }^{\mathbf{1 2 5}}$-labeled hurnan epidermal growth factor. Binding, internalization, and degradation in human fibroblasts. $\mathrm{J}$ Cell Biol. 71: 159-171.

Claude, P., E. Hawrot, D. A. Dunis, and R. B. Campenot (1982) Binding, internalization, and retrograde transport of ${ }^{125} \mathrm{I}$-nerve growth factor in cultured rat sympathetic neurons. J. Neurosci. 2: 431-442.

Cohen, P., A. Sutter, G. Landreth, A. Zimmermann, and E. M. Shooter (1980) Oxidation of tryptophan-21 alters the biological activity and receptor binding characteristics of mouse nerve growth factor. J. Biol. Chem. 255 2949-2954.

Frazier, W. A., L. F. Boyd, and R. A. Bradshaw (1974) Properties of the specific binding of ${ }^{126}$-nerve growth factor to responsive peripheral neu rons. J. Biol. Chem. 249: 5513-5519.

Goldstein, J. L., R. G. W. Anderson, and M. S. Brown (1979) Coated pits coated vesicles, and receptor-mediated endocytosis. Nature 279: 679685 .

Greene, L. A., and A. S. Tishler (1976) Establishment of a noradrenergic clonal line of rat adrenal pheochromocytoma cells which respond to nerve growth factor. Proc. Natl. Acad. Sci. U. S. A. 73: 2424-2428.

Herrup, K, and E. M. Shooter (1973) Propertics of the fetal nerve growth factor receptor: Avian dorsal root ganglia. Proc. Natl. Acad. Sci. U. S. A. 70: 3884-3888.

Ishii, D. N. (1978) Effect of tumor promoters on the response of cultured embryonic chick ganglia to nerve growth factor. Cancer Res. 38: 38863893.

Ishii, D. N. (1982a) Effect of the suspected tumor promoters saccharin, cyclamate, and phenol on nerve growth factor binding and response in cultured embryonic chick ganglia. Cancer Res. 42: 429-432.

Ishii, D. N. (1982b) Inhibition of ${ }^{125}$-nerve growth factor binding by the suspected tumor promoters saccharin and cyclamate. J. Natl. Cancer Inst. 68: $299 \cdot 303$

Ishii, D. N., and E. M. Shooter (1975) Regulation of nerve growth factor synthesis in mouse submaxillary glands by testosterone. J. Neurochem. 25: 843-851.

Jacobs, S., K. J. Chang, and P. Cuatrecasas (1975) Estimation of hormone receptor affinity by competitive displacement of labeled ligand: Effect of concentration of receptor and labeled ligand. Biochem. Biophys. Res. Commun. 66: 687-692.

Landreth, G. E., and E. M. Shooter (1980) Nerve growth factor receptors on PC12 cells: Ligand-induced conversion from low- to high-affinity states. Proc. Natl. Acad. Sci. U. S. A. 77: 4751-4755.

Lyons, R. C., R. W. Stach, and J. R. Perez-Polo (1983) Binding constants of isolated NGF-receptors. Biochem. Biophys. Res. Commun. 115: 368-374

Mobley, W. C., A. C. Server, D. N. Ishii, R. J. Riopelle, and E. M. Shooter (1977a) Nerve growth factor. Part I. New Engl. J. Med. 297: 1096-1104.

Mobley, W. C., A. C. Server, D. N. Ishii, R. J. Riopelle, and E. M. Shooter (1977b) Nerve growth factor. Part II. N. Engl. J. Med. 297: 1149-1158.

Mobley, W. C., A. C. Server, D. N. Ishii, R. J. Riopelle, and E. M. Shooter (1977c) Nerve growth factor. Part III. N. Engl. J. Med. 297: 1211-1218.

Moore, W. J. (1962) Physical Chemistry, pp. 253-322, Prentice-Hall, Inc., Englewood Cliffs, NJ.

Olender, E. J. and R. W. Stach (1980) Sequestration of ${ }^{125} /$ labeled betanerve growth factor by sympathetic neurons. J. Biol. Chem. 255: 93389343.

Olender, E. J., B. J. Wagner, and R. W. Stach (1981) Sequestration of ${ }^{125}$ labeled nerve growth factor by embryonic sensory neurons. J. Neurochem 37: 436-442.

Perez-Polo, J. R., K. Werbach-Perez, and E. Tiffany-Castiglioni (1979) A human clonal cell line model of differentiating neurons. Dev. Biol. 71: 341355.

Recio-Pinto, E, and D. N. Ishii (1984) Effects of insulin, insulinlike growth factor-II, and nerve growth factor on neurite outgrowth in cultured human neuroblastoma cells. Brain Res. 302: 323-334.

Recio-Pinto, E., F. F. Lang, and D. N. Ishii (1984) Insulin and insulin-like growth factor ll permit nerve growth factor binding and the neurite formation response in cultured human neuroblastoma cells. Proc. Natl. Acad. Sci. U. S. A. $81: 2562-2566$.

Reynolds, C. P., and J. R. Perez-Polo (1981) Induction of neurite outgrowth in the IMR-32 human neuroblastoma cell line by nerve growth factor. J. Neurosci. Res. 6: 319-325.

Schechter, A. L., and M. A. Bothwell (1981) Nerve growth factor receptors on PC12 cells: Evidence for two receptor classes with differing cytoskeletal association. Cell 24: 867-874.

Schlesinger, H. R., J. M. Gerson, P. S. Moorhead, H. Maguire, and K. Hummeler (1976) Establishment and characterization of human neuroblastoma cell lines. Cancer Res. 36: 3094-3100.

Shiu, R. P. C., and H. G. Friesen (1974) Properties of a prolactin receptor from rabbit mammary gland. Biochem. J. 140: 301-311.

Shooter, E. M., B. A. Yankner, G. E. Landreth, and A. Sutter (1981) Biosynthesis and mechanism of action of nerve growth factor. Recent Prog. Horm. Res. 37: 417-446.

Sonnenfeld, K. H., and D. N. Ishii (1982) Nerve growth factor effects and receptors in cultured human neuroblastoma cell lines. J. Neurosci. Res. 8: 375-391

Spinelli, W., and D. N. Ishii (1983) Tumor promoter receptors regulating neurite formation in cultured human neuroblastoma cells. Cancer Res. 43: 4119-4125.

Spinelli, W., K. H. Sonnenfeld, and D. N. Ishii (1982) Effects of phorbol ester tumor promoters and nerve growth tactor on neurite outgrowth in cultured human neuroblastoma cells. Cancer Res. 42: 5067-5073.

Stach, R. W., and B. J. Wagner (1982) Decrease in the number of lower affinity (type II) nerve growth factor receptors on embryonic sensory neurons does not affect fiber outgrowth. J. Neurosci. Res. 7: 103-110.

Stephenson, R. P. (1956) A modification of receptor theory. Br. J. Pharmacol. 11: 379-393.

Sutter, A., R. J. Riopelle, R. M. Harris-Warrick, and E. M. Shooter (1979) Nerve growth factor receptors: Characterization of two distinct classes of binding sites on chick embryo sensory ganglia cells. J. Biol. Chem. 254: 4972-4982.

Tumilowicz, J. J., W. W. Nichols, J. J. Cholon, and A. E. Greene (1970) Definition of a continuous human cell line derived from neuroblastoma. Cancer Res. 30: 2110-2118.

Vale, R. D., and E. M. Shooter (1982) Alteration of binding properties and cytoskeletal attachment of nerve growth factor receptors in PC12 cells by whoat gorm agglutinin. J. Coll Biol. 94: 710 -717

Vale, R. D., M. Hosang, and E. M. Shooter (1983) Nerve growth factor 
receptors on PC12 cells: Two distinct binding species. Trans. Am. Soc. Neurochem. 14: 136a.

Varon, S., J. Nomura, and E. M. Shooter (1968) Reversible dissociation of mouse nerve growth factor protein into subunits. Biochemistry 7: 12961303.

Williams, L. T., and R. S. Lefkowitz (1978) Receptor Binding Studies in Adrenergic Pharmacology, Raven Press, New York.
Yankner, B. A., and E. M. Shooter (1982) The biology and mechanism of action of nerve growth factor. Annu. Rev. Biochem. 51: 845-868.

Zimmermann, A., A. Sutter, and E. M. Shooter (1981) Monoclonal antibodies against beta-nerve growth factor and their effects on receptor binding and biological activity. Proc. Natl. Acad. Sci. U. S. A. 78: 4611-4615. 